\title{
THE AGENCY SHOP, FEDERAL LAW, AND THE RIGHT-TO-WORK STATES*
}

ON September 29, 1961, the National Labor Relations Board, in a reversal of policy, held that federal law does not bar the operation of an agency shop in a state which bans the union shop. ${ }^{1}$ The agency shop is a union security device requiring all employees, as a condition of employment, to pay to the union "support money" equivalent to union dues and fees." It thus differs from the union shop, which conditions employment on actual membership. ${ }^{3}$ Union lawyers have attempted to employ the agency shop as a means of mitigating the effect of "right-to-work laws;"4 these laws, in force in nineteen states, ${ }^{5}$ prohibit all agreements conditioning employment on member-

\footnotetext{
*General Motors Corp., 47 L.R.R.M. 1306, rev'd an reconsideration, 48 L.R.R.M. 1659 (Sept. 29, 1961).

1. The case referred to was reported as General Motors Corp., 47 L.R.R.M. 1306, rev'd on reconsideration, 48 I.R.R.M. 1659 (Sept. 29, 1961).

2. A typical agency shop clause is found in Meade Elec. Co. v. Hagberg, 129 Ind. App. 631, 633-34, 159 N.E.2d 408, 409-10 (1959) :

Section 1. Agency Shop. (a) Membership in the Union is not compulsory. Employees have the right to join, not join, maintain or drop their membership in the Union, as they see fit. Neither party shall exert any pressure on or discriminate against an employee as regards such matters.

(b) ....

(c) In accordance with the policy set forth under sub-paragraphs (a) and (b) of this Article, all employees shall, as a condition of continued employment, pay to the Union, the employee's exclusive collective bargaining representative, an amount of money equal to that paid by other employees in the bargaining unit who are members of the Union, which shall be limited to an amount of money equal to the Union's regular and usual initiation fees, and its regular and usual dues and its general and uniform assessments. For existing employees, such payments shall commence fortyfive (45) days following the date of execution of this Agreement and for new employees, the payment shall start forty-five (45) days following the date of employment.
}

The proposal of the union in General Motors was, in fact, based on this very clause. See Motion of the UAW for Reconsideration and Oral Argument, pp. 9-10.

It has been estimated that such clauses appear in $6 \%$ of all union contracts. Id. at 2 .

3. See LAB. Rex. Rep. (LRX) 643 (1960).

4. See, e.g., Higgins v. Cardinal Mfg. Co., 188 Kan. 11, 360 P.2d 456 (1961), ccrt. denied, 30 U.S.L. WeEk 3107 (Oct. 10, 1961) (No. 208) ; Meade Elec. Co. v. Hagberg, 129 Ind. App. 631, 159 N.E.2d 408 (1959) ; Baldwin v. Arizona Flame Restaurant, 82 Ariz. 385, 313 P.2d 759 (1957).

5. Ala. Code Ann, tit. $26 \S 375$ (1958); Ariz. Rev. Stat. Ann. $\S \S 23-1301$ to -1307 (1956) ; Ark. Stat. Ann. $\$ \S 81-201$ to -205 (1960); Fla. Stat. Ann. Const., Decl. of RTs. \$ 12 (Supp. 1960); GA. Code ANN. \$§ 54-901 to -905 (1961) ; Ind. STAt. Ann, \$§ 40-2701 to -2706 (Supp. 1961) ; Iowa Code And. \$\$ 736A.1 to 8 (1950) ; Kan. Const. Art. 15, § 12 (1958) ; Miss. Code ANN. $\$ 6984.5$ (Supp. 1958) ; Neb. Const. Art. XV, §§ 13-15, Neb. Rev. Stat. Ann. \$§ 48-217 to -219 (1952) ; Nev. Rev. Stat. \$\$ 613.230 to -300 (1957); 
ship in a labor organization. The Board's opinion, handed down on reconsideration of a case involving General Motors and the United Auto Workers, may provide a means of obtaining some measure of union security even in right-to-work states.

\section{The Factual Background}

General Motors and the United Auto Workers were operating under a national agreement which provided, inter alia, for the union shop. ${ }^{6}$ The contract contained an exculpatory clause, which waived the union security provision "in any state which prohibits, or otherwise makes unlawful, membership in a labor union as a condition of employment." Indiana, the locus of the dispute, had such a statute. ${ }^{8}$ But in 1959, the Indiana Appellate Court, in Mcade Elec. Co. v. Hagberg, ${ }^{9}$ had held the agency shop legal under Indiana's right-to-work law. Four months after Hagberg, the union requested bargaining concerning a proposed supplementary agreement covering nine plants in six Indiana cities. ${ }^{10}$ Under the proposed agreement, all workers subject to its terms would be required to commence payments to the union 31 days after the effective date of the contract, or the date of hire, whichever was later. The required payments would be equivalent to the initiation fees and monthly dues of each of the affected locals. ${ }^{11}$ A week later, the employer, claiming that the proposed agreement was illegal under the Taft-Hartley Act, ${ }^{12}$ refused to participate in the requested negotiations. ${ }^{13}$ Two days after that, the union filed charges under sections $8(a)(1)^{14}$ and $8(a)(5)^{15}$ of

N.C. Gen. Stat. Ann. $\S$ 95-78 to -84 (1958); N.D. Cent. Code § 34-01-14 (1960); S.C. CoDE ANn. $\S \S 40-46$ to -46.11 (Supp. 1960) ; S.D. Code $\S \$ 17.1101,17.9914$ (Supp. 1952) ; Tenn. Code Ann. $\$ \$ 50-208$ to -212 (1955); Tex. Rev. Crv. Stat. art. 5154g (Supp. 1960) ; UtAr Code ANn. \$\$ 34-16-1 to -16-18 (Supp. 1961) ; VA. Code ANN. \$\$ 40-68 to -74.5 (Supp. 1960).

6. General Motors Corp., 47 L.R.R.M. 1306, 1307 (1961).

7. Ibid.

8. IND. STAT. ANN. $\$ \$ 40-2701$ to -2706 (Supp. 1961).

9. 129 Ind. App. 631, 159 N.E.2d 408 (1959). This was not a decision by the highest court in the state.

10. 47 L.R.R.M. at 1307.

11. Ibid.

12. Labor Management Relations Act, as amended, 61 Stat. 136 (1947), 29 U.S.C. §§ 141-97 (1958).

13. 47 L.R.R.M. at 1307.

14. Labor Management Relations Act $\S 8(a)(1), 61$ Stat. 140 (1947), 29 U.S.C. § 158 (a) (1) (1958), provides:

It shall be an unfair labor practice for an employer (1) to interfere with, restrain, or coerce employees in the exercise of the rights guaranteed in section $8 . .$.

Labor Management Relations Act $\S 7,61$ Stat. 140 (1947), 29 U.S.C. $\$ 157$ (1958), provides:

Employees shall have the right to self-organization, to form, join, or assist labor organizations, to bargain collectively through representatives of their own choosing, 
Taft-Hartley, alleging the employer's refusal to bargain. ${ }^{16}$ The parties agreed that, if the proposed agency shop agreement were legal, it would be a mandatory subject of bargaining. ${ }^{17}$ The Board, in order to determine whether the employer's refusal to bargain was an unfair labor practice, was therefore required to pass on the legality of the agency shop in Indiana, a right-to-work state. ${ }^{18}$

\section{The Opinion: Conflicting Constructions of Section 8(a)(3)}

The parties placed opposing interpretations on sections $7, S(a)(1)$ and 8 (a) (3) of Taft-Hartley. Section 7 gives workers the right, inter alia, to refrain from assisting a labor organization. ${ }^{19}$ Section $8(a)(1)$ proscribes employer interference with "the exercise of rights guaranteed in section 7."20 And section 8 (a) (3) prohibits employer discrimination in regard to hire or tenure of employment; but its first proviso specifically permits employers to enter agreements conditioning employment upon membership in a labor organization. ${ }^{21}$ The question arises, therefore, whether the only device which meets the standard of the above proviso is an agreement conditioning employment on membership, in the most literal sense, or whether section 8 (a) (3) might be construed more broadly to include the agency shop as well. The employer argued for a narrow construction: "to condition employment on

and to engage in other concerted activities for the purpose of collective bargaining or other mutual aid or protection, and shall also have the right to refrain from any or all of such activities except to the extent that such right may be affected by an agreement requiring membership in a labor organization as a condition of employment as authorized in section 8 (a) (3).

15. Labor Management Relations Act $\S 8(a)(5), 61$ Stat. 141 (1947), 29 U.S.C. § 158(a) (5) (1958), provides: "It shall be an unfair labor practice for an employer ... (5) to refuse to bargain collectively with the representatives of his employees. . . ."

16. 47 L.R.R.M. at 1307. The facts in the case were stipulated. Ibid.

17. Ibid. The employer conceded that, if the agency shop were legal and a mandatory subject of bargaining, refusal to bargain with respect to it would constitute a violation of $\S$ $8(a)$ (5). Ibid. It is also worthy of note that the parties agreed that no appeal would be taken from the decision of the Board. See N.Y. Times, September 30, 1961, p. 13, col. 5.

18. The various stipulations in the case, see note 16 supra and note 17 supra and accompanying text, suggest the possibility that the parties were seeking something like a declaratory judgment on the legality of the proposed agency shop term of the contract.

19. See note 14 supra.

20. Ibid.

21. Labor Management Relations Act $\S 8(\mathrm{a})(3), 61$ Stat. 140 (1947), 29 U.S.C. $\S$ 158(a) (3) (1958), provides in part:

It shall be an unfair labor practice for an employer ... (3) by discrimination in regard to hire or tenure of employment or any term or condition of employment to encourage or discourage membership in any labor organization: Provided, That nothing in this Act ... shall preclude an employer from making an agreement with a labor organization ... to require as a condition of employment membership therein on or after the thirtieth day following the beginning of such employment or the effective date of such agreement, whichever is the later.... 
anything other than membership in a labor organization is contrary to the mandate of the statute."22 The employer argued further that such a construction would remove the agency shop agreement from the protection of the proviso, thereby placing it under the ban of section 8 (a)(1), as an illegal infringement of the worker's right to refrain from union activity. Moreover, enforcement of the agreement, resulting in the discharge of dissenting workers, would constitute discrimination tending to encourage membership. Thus the employer, absent the proviso's protection, would be subject to charges under section S(a)(3). ${ }^{23}$ The union and the Board's General Counsel, on the other hand, urged a broad interpretation of the proviso: it merely defines the outer limits of permissible union security, they argued, and should be read to subsume lesser forms of union security arrangements such as the agency shop. ${ }^{24}$ Rejecting this argument, the majority of the Board held the proposed clause illegal on its first hearing of the case. ${ }^{25}$ The losing parties however, shortly moved for reconsideration. ${ }^{26}$ Granting these motions, the Board in its second decision reversed itself, adopting the union position without substantial modification. ${ }^{27}$

The legislative history favors a construction of section $8(a)(3)$ validating the agency shop. The predecessor of $8(a)(3)$-the old section $8(3)$ of the Wagner Act-permitted even the closed shop $;^{28}$ and within this outer limit, lesser forms of union security, including a device very much resembling the agency shop, were held legal. ${ }^{29}$ Presumably, section $8(a)(3)$ was intended to do no more than abolish the closed shop. Senator Taft stated in the debates that

the rule adopted by the committee is substantially the rule now in effect in Canada. ... [T] he present rule in Canada is that there can be a closed shop or union shop, and the union does not have to admit an employee who applies for union membership, but [if] the employee ... pays dues without joining the union, he has the right to be employed. ${ }^{30}$

Senator Taft's reference was to an arbitration decision by Justice I. C. Rand of the Canadian Supreme Court. In a union security dispute between the UAW and the Ford Motor Co. of Canada, Justice Rand had denied the

22. Brief of Respondent, pp. 13-14.

23. Id. at $19-20$.

24. 47 L.R.R.M. at 1309. The original brief of the UAW was unavailable for examination, as was that of the General Counsel. The same point is reiterated in Motion of the UAW for Reconsideration and Oral Argument, p. 4.

25. General Motors Corp., 47 L.R.R.M. 1306 (1961).

26. The motions did not go entirely unopposed. See, e.g., Statement and Motion of Respondent in Opposition to Applications For Reconsideration.

27. General Motors Corp., 48 L.R.R.M. 1659 (1961).

28. National Labor Relations Act $\$ 8(3), 49$ Stat. 452 (1935).

29. See Lab. Ret. Rep. (LRX) 643, 644 (1960). See Public Serv. Co. of Colorado, 89 N.L.R.B. 418 (1950) (validating support money provision inserted in collective agreement prior to effective date of Taft-Hartley amendments).

30. 93 Cong. REc. 4887 (1947) (remarks of Senator Taft). 
union's request for a full union shop; but he had permitted regular checkoff of an amount equivalent to union dues from the wages of non-union, as well as union, employees. ${ }^{31}$ Thus the model from which the framers worked in drafting 8(a) (3) was, indeed, an agency shop.

The NLRB has previously interpreted the section as authorizing an agency shop in a non-right-to-work state. In American Seating $\mathrm{Co}_{0}{ }^{32}$ the Board found

that Congress intended not to illegalize the practice of obtaining support payments from nonunion members who would otherwise be "free riders." . . . [Thus they found] that the provision for support payments in the instant contract does not exceed the union-security payments authorized by the Act. ${ }^{33}$

The first proviso of $8(\mathrm{a})$ (3) was interpreted as validating a contract which required employees to become or remain members of the union, but permitted religious objectors instead to tender support money equivalent to monthly union dues. ${ }^{34}$ No case since American Seating has cast new light on the legislative history with reference to the agency shop. And the opinions in the General Motors Corp. case urging a narrow reading of the first proviso-i.e., the majority in the first decision, and the dissent in the second-adduce no legislative history to the contrary.

The narrow constructionists attack the problem from another direction, contending that broad construction will lead to unwarranted diversity in the law of union security. Member Leedom, who advocated narrow construction in both opinions, argued that, in the second proceeding, his colleagues had found the agency shop lawful under the federal statute because the Indiana court had validated it under state law. ${ }^{35}$ The implication of such a holding, reasoned Leedom, was that the NLRB would follow state law in this area, whatever that law might be. And since state laws dealing with union security vary-some proscribing only the union shop ${ }^{36}$ and some banning the agency shop as well ${ }^{37}$ - the Board, in following state law, would be acting con-

31. Ford Motor Co. of Canada, 1 Lab. Arb. 439, 17 L.R.R.M. 2782 (1946).

32. 98 N.L.R.B. 800 (1952).

33. Id. at 802 .

34. Id. at 801-02.

35. 48 I.R.R.M. 1659, 1663 n.28.

36. See statutes cited note 5 supra. The laws of Arizona, Florida, Indiana, Kansas, Nebraska, Nevada, North Dakota, South Dakota, and Texas outlaw only agreements conditioning employment upon "membership" in a labor organization.

37. See statutes cited note 5 supra. The laws of Alabama, Arkansas, Georgia, Iowa, Mississippi, North Carolina, South Carolina, Tennessee, Utah, and Virginia, in addition to banning agreements conditioning employment on "membership" in a labor organization, contain provisions resembling the following, which appears as VA. CODE ANN. § 40-72 (1953):

No employer shall require any person, as a condition of employment or continuation of employment, to pay any dues, fees or other charges of any kind to any labor union or labor organization. 
trary to the notion of uniformity often cited as the major policy underlying the federal statute. ${ }^{38}$ Although Taft-Hartley section 14 (b) ${ }^{39}$-which allows the states to ban agreements conditioning employment on membershipexhibits some limited congressional intent to depart from uniformity, Leedom argued that it does so only to the extent of allowing the states to render the first proviso to $8(a)(3)$ wholly inapplicable. Thus, if one reads the word "membership" in 8(a) (3) 40 narrowly to authorize only the union shop, a state law banning agreements conditioning employment on membership would outlaw only the union shop. If "membership" in $8(a)(3)$ is read broadly to validate both the agency and union shops, such a state law would ban both; the state, because of the nature of $14(\mathrm{~b})$, has no discretion to outlaw one and not the other. ${ }^{41}$

Moreover, Member Leedom indicts the position of the broad constructionists in another fashion; legitimizing the agency shop in a state with a right-to work law, he claims, will subvert the purpose of such a law. The union shop, valid under the first proviso to 8 (a) (3), permits "coercion" of membership in a labor organization; the law of every right-to-work state, however, prohibits the union shop, thereby expressing a policy against "coercion." The agency shop is inherently coercive, argues Leedom, because, while requiring the agency shop employee to pay the equivalent of union dues and fees, it denies him all the benefits of union membership ${ }^{42}$ apart from those flowing directly from the collective agreement. ${ }^{43}$ A desire for these benefits-purchased, but not received-will encourage the non-union worker to join, for, as Leedom asks: "[W] ho can say . . that a man forced to buy a cake will not eat it"?44

Thus, Leedom contends that the broad constructionists' reliance on American Seating ${ }^{45}$ and a similar case decided under the Wagner Act, ${ }^{40}$ is misplaced. Unlike the instant case," each of those cases arose in a state with "no legal impediment" - a right-to-work law-to union shop contracts. The agency

38. 48 L.R.R.M. 1659,1663 n.28. On the notion of uniformity see, e.g., Garner v. Teamsters Union, 346 U.S. 485, 490-91 (1953).

39. Labor Management Relations Act § 14(b), 61 Stat. 151 (1947), 29 U.S.C. § 154(b) (1958), which provides:

Nothing in this Act shall be construed as authorizing the execution or application of agreements requiring membership in a labor organization as a condition of employment in any State or Territory in which such execution or application is prohibited by State or Territorial law.

40. See note 21 supra.

41. 48. L.R.R.M. 1659, 1663 n.28.

42. See text accompanying note 68 infra.

43. See text accompanying notes $65-68$ infra.

44. 48 L.R.R.M. at 1663-64.

45. American Seating Co., 98 N.L.R.B. 800 (1952).

46. Public Serv. Co. of Colorado, 89 N.L.R.B. 418 (1950).

47. General Motors Corp., 47 L.R.R.M. 1306, rev'd on reconsideration, 48 L.R.R.M. 1659 (1961). 
shops permitted by the Board in the earlier cases were thus valid as alternatives to existing union shop contracts. Hence, Leedom concludes,

the choice extended to employees there, between membership and support which did not involve membership, is wholly different from the "Hobson's choice" which the UAW would extend to the employees here. ${ }^{48}$

It is no answer to argue that the employee can join a union in either case, reasons Leedom, for the very purpose of a right-to-work law is to immunize a worker from such coercion. ${ }^{48}$

Member Leedom's first argument, alleging the need for operational uniformity in the law of union security, seems naive in light of section 14(b). Although willing to admit that that section makes some limited departure from the policy of uniformity, he takes little notice of manifest congressional intent. The House Conference Report on the bill which became the Taft-Hartley Act states that

under the House bill there was included a new section 13 of the National Labor Relations Act to assure that nothing in the act was to be construed as authorizing any closed shop, union shop, maintenance of membership, or other form of compulsory unionism agreement in any State where the execution of such agreement would be contrary to State law. ... The conference agreement, in section 14(b) contains a provision having the same effect. ${ }^{50}$

The language of the House Report is similar:

[B]y section 13 the United States expressly declares the subject of compulsory unionism one that the States may regulate concurrently with the United States, ... notwithstanding that the State laws limit compulsory unionism more drastically than does Federal law. ${ }^{51}$

Hence, the "uniformity" argument of Member Leedom is inappropriate here. The cases which have dealt most directly with the problem of uniformitythose involving preemption of state law by the federal statute ${ }^{52}$-have been

48. 48 L.R.R.M. 1659, 1664. For the lover of esoterica, the following definition of "Hobson's choice" appears in 14 Encyc. Antericans 306 (1956) :

"Hobson's choice" may best be translated, "that or nothing." Thomas Hobson was a carrier and innkeeper at Cambridge, who erected the handsome conduit there and settled "seven lays" of pasture ground toward its maintenance. But the story about him, as told by The Spectator, is as follows: "He kept a stable of forty good cattle, always ready and fit for travelling; but when a man came for a horse he was led into the stable, where there was great choice, but was obliged to take the horse that stood nearest to the stable door, so that every customer was alike well served according to his chance, and every horse ridden with the same justice." Milton wrote two quibbling epitaphs upon this eccentric character.

Hobson died in the year 1630. 11 Encyc. Britannica 615 (1957).

49. 48 L.R.R.M. at 1664.

50. 1 NLRB, Legislative History of the Labor-Managenent Relations Act, 1947564 (1948) (emphasis added) [hereinafter cited as 1 LEG. HrsT.].

51. 1 LEg. HIST. 325 (1948).

52. See, e.g., San Diego Bldg. Trades Council v. Garmon, 359 U.S. 236 (1959); 
rationalized largely in terms of the necessity that state courts defer to the primary jurisdiction of the NLRB. ${ }^{53}$ Even Leedom would concede that, where the states have enacted measures pursuant to section 14(b), the Board is displaced in favor of the state courts. ${ }^{54}$

The answer to Leedom's "coercion" argument is very similar to the answer to his "uniformity" contention. Leedom seems to be arguing that allowance of the agency shop-and whatever coercion it may entail-in a right-to-work jurisdiction will subvert the purpose of the state law banning the union shop. Yet, he again appears to forget the relevant legislative history..$^{55}$ It is true that the Board's second decision in General Motors Corp. will, in effect, allow the union in Indiana to coerce workers; and such coercion may or may not be inconsistent with the policy underlying the state's ban of the union shop. But Congress has made this the concern of the state, not the Board..$^{56}$ In fact, the Board's opinion does not affect the situation in Indiana at all. ${ }^{57}$ If one concurs with Leedom that the purpose of the state's right-to-work law was subverted, responsibility for such subversion rests with the Indiana Appellate Court which in Hagberg ${ }^{58}$ legitimized the agency shop under state law. At least one other state has interpreted an identical provision to ban the agency shop $;^{\text {to }}$ the statutes of several more states in terms ban the agency shop. ${ }^{60}$

Garner v. Teamsters Union, 346 U.S. 485 (1953). See generally Note, 70 Y ALE L.J. 441 (1961).

53. See, e.g., San Diego Bldg. Trades Council v. Garmon, 359 U.S. 236, 242 (1959); Garner v. Teamsters Union, 346 U.S. 485, 490-91 (1953).

54. See text of $\$ 14(\mathrm{~b})$, note 39 supra. Since Congress has in $\S 14(\mathrm{~b})$ made a clear and specific exception to the general notion of uniformity reflected in the preemption cases, it seems a useless exercise, given the present state of the law, to attempt to salvage some remnant of the doctrine.

55. See text at notes 50-51 supra.

56. Ibid.

57. The majority opinion in the second General Motors Corp. case states clearly that the case is being decided solely under federal law. 48 L.R.R.M. at 1660 . The effect of the decision was to legalize the agency shop as a matter of federal law. To the extent that the states may, pursuant to $\S 14(\mathrm{~b})$, outlaw union security devices legitimate under federal law, the fate of the agency shop remains a matter of state decision. Only if the Board's ruling in the first General Motors Corp. case-that the agency shop was illegal in a right-to-work state as a matter of federal law-had been permitted to stand, would the issue have been taken from the states. The House Report declares: "It goes without saying that no State may invalidate, as to agreements affecting commerce, restrictions or conditions that the amended Labor Act will put upon compulsory unionism." 1 LEG. HIST. 325.

58. Meade Elec. Co. v. Hagberg, 129 Ind. App. 631, 159 N.E.2d 408 (1959).

59. Higgins v. Cardinal Mfg. Co., 188 Kan. 11, 360 P.2d 456 (1961), cert. denied, 30 U.S.L. WEEK 3107 (October 10, 1961) (No. 208). The Florida provision is presently being tested in Schermerhorn v. Local 1625, Retail Clerks Int'l Ass'n, Case No. 61-7, Fla. Dist. Ct. App., Opinion filed September 14, 1961. The opinion of the Florida court is being held in abeyance pending adjudication of the procedural technicality. See letter of Peter $L$. Nimkoff, Research Aide to Judge Carroll of the Florida Court, September 22, 1961. (On file in Yale Law Library).

60. See note 37 supra. 


\section{Implications of the Opinion Under Federal Law: The Agency Shop-Closed Union}

Although federal law does not prohibit the agency shop, the status of this device is questionable when the union bars agency shop employees from union membership. The majority opinion in the second General Motors Corp. case explicitly assumes that all General Motors employees covered by the agreement would be given the option of becoming members of the UAW. ${ }^{\text {BI }}$ Some unions, however, restrict their membership on racial, religious, political, and other grounds. ${ }^{62}$ Such unions, through their collective agreements, might compel employees to pay the equivalent of union dues as a condition of employment, while denying them the benefits of union membership. The majority expressly reserves decision on the legality of the agency shop in such a case. ${ }^{63}$

It is unclear whether Taft-Hartley section 8(b) (2) permits or prohibits the agency shop-closed union. The section forbids unions "to cause . . an employer . . to discriminate against an employee with respect to whom membership in a union has been denied ... on some ground other than his failure to tender the periodic dues and initiation fees uniformly required as a condition of acquiring or retaining membership." ${ }^{44}$ Under one reading of the section, an employee to whom the union is closed, e.g., on the basis of race, is and remains indefinitely protected from discrimination by the employer at the instigation of the union. Assuming an agency shop-closed union situation, an employee who refused to pay union dues as required by the contract would be protected from union pressure for discharge. But another possible reading of 8 (b) (2) is that an employee is protected from union pressure for his discharge so long as he continues to pay dues; once he ceases to pay dues, he falls within the statutory exception to his protection, and the union may instigate, and the employer may carry out his discharge. Thus, the Board might hold the agency shop legal even in a closed union context. Steele v. Lonisville \& N.R. Co ${ }^{\text {G5 }}$ may provide additional support for that position. In that case the United States Supreme Court imposed upon unions a duty to represent fairly and equally all workers within the bargaining unit-non-members as well as members. ${ }^{66}$ To the extent that this duty safeguards the right of non-members to all benefits flowing from the collective bargaining process and the grievance procedure, ${ }^{67}$ agency shop employees barred from union membership are as

61. 48 L.R.R.M. at 1660 .

62. See Summers. The Right to Jonn a Union, 47 Colum. L. Rev. 33, 33-36 (1947).

63. 48 L.R.R.M. at 1660-61 \& n.11.

64. Labor Management Relations Act § 8(b) (2), 61 Stat. 141 (1947), 29 U.S.C. § 158 (b) (2) (1958).

65. 323 U.S. 192 (1944). The case arose under the Railway Labor Act, but the doctrine was extended to apply to workers subject to Taft-Hartley in Ford Motor Co. v. Huffman, 345 U.S. 330, 337 (1953) (dictum).

66. 323 U.S. at 204.

67. The duty was extended to cover the grievance procedure in Conley v. Gibson, 355 U.S. 41 (1957). 
well protected as the non-member plaintiffs in Steele. But other benefits of union membership-such as participation in the union's educational fund, pension fund, strike benefits, and elections-which are available to dues-paying members, ${ }^{08}$ remain unavailable to agency shop employees who make equivalent payments.

It has been argued that the Steele doctrine as it stands is imperfect-that fair representation is impossible without union membership. ${ }^{60}$ The logical conclusion of such an argument is that Steele should be extended to require unions to admit to membership all who wish to join. ${ }^{70}$ Such an argument takes on special force in the case of those employees who are compelled to pay the equivalent of union dues and fees. But courts have been chary about compelling admission, ${ }^{71}$ especially in view of the mandate of section 8 (b) (1) (A) that "the right of a labor organization to prescribe its own rules with respect to the acquisition or retention of membership therein"72 shall not be impaired. It would be more realistic, therefore, to expect a holding such as that in James v. Marinship Corp., ${ }^{73}$ where the California Supreme Court, in a closed shopclosed union situation, required that the union either open its membership or relinquish the closed shop. ${ }^{74}$ Such an alternative holding-amounting to a finding that the agency shop, when coupled with a closed union, was illegalmight well be adopted by the Board.

The legislative history of section 8 (a) (3) would support such a holding. Congress in passing section $8(a)(3)$ was principally concerned with outlawing the closed shop, while at the same time allowing unions some measure of protection against "free riders." 75 It would be a misreading of the policy implicit in the section to require non-union employees to pay for benefits, unrelated to the bargaining process, which are denied them by the union. An analogous problem was recently faced by the United States Supreme Court in

68. There was some dispute in the first General Motors Corp. case as to whether this was true in that case, even without the option to join. See, e.g., 47 L.R.R.M. 1309 \& n.6, 1315 \& n.41. However, given the reasons for closing a union, see Summers, supra note 62 , at 36 , it would almost certainly be true of the agency shop-closed union situation.

69. See Wellington, The Constitution, the Labor Union, and "Governmental Action," 70 Y ALE L.J. 345, 372-74 (1961) ; Givens, The Enfranchisement of Employees Arbitrarily Rejected for Union Membership, 11 LAB. L.J. 809, 812 (1960).

70. See Wellington, supra note 69 , at 374 .

71. See Givens, supra note 69 , at 812 . The only reported case compelling admission to a union appears to be Thorman v. International Alliance of Theatrical Stage Employees, 49 Cal.2d 638, 320 P.2d 494 (1958), modifying and affirming 149 Cal. Adv. App. 116, 307 P.2d 1026 (App. Dep't 1957), discussed in Wellington, Union Democracy and Fair Represcntation: Federal Responsibility in a Federal System, 67 YaLE L.J. 1327, 1343-44 (1958).

72. Labor Management Relations Act $\$ 8(\mathrm{~b})(1)(A), 61$ Stat. 141 (1947), 29 U.S.C. $\S 158(\mathrm{~b})(1)(\mathrm{A})(1958)$.

73. 25 Cal.2d 721, 155 P.2d 329 (1944).

74. Id. at 745,155 P.2d at 342 .

75. The House Report states :

The bill prohibits what is commonly known as the closed shop, or any form of 
International Ass'n of Machinists v. Street. ${ }^{76}$ There, a labor organization, operating under a union shop expressly authorized by the Railway Labor Act, expended dues money for political purposes which six workers found objectionable. To avoid deciding a constitutional question, the Court held that the statute could not be read to authorize such expenditures in the face of objections from those whose money the union was using. ${ }^{77}$ The reasoning of Street could likewise be applied to the agency shop-closed union situation under Taft-Hartley: Section 8(a) (3) may not be read to allow union requirement of more than the cost of collective bargaining. ${ }^{78}$ But it is not likely that any system of pro-rata payments to the union will be acceptable to organized labor, for administration of such a scheme, under the prevalent practice of checkoff, ${ }^{79}$ would involve detailed management examination of union books. ${ }^{80}$ Moreover, exact allocations of the cost of bargaining-as distinct from other union activity-would be difficult, if not impossible, to make. ${ }^{31}$

compulsory unionism that requires a person to be a member of a union in good standing when the employer hires him.

1 LEG. HIST. 324 (1948).

The United States Supreme Court, in Radio Officers' Union v. NLRB, 347 U.S. 17, 40-41 (1954), referring to the legislative history, declared:

Lengthy legislative debate preceded the 1947 amendment to the Act. . . This legislative history clearly indicates that Congress intended to prevent utilization of union security agreements for any purpose other than to compel payment of union dues and fees. Thus Congress recognized the validity of the unions' concern about "free riders," i.e., employees who receive the benefits of union representation but are unwilling to contribute their share of financial support to such union, and gave unions the power to contract to meet that problem while withholding from unions the power to cause the discharge of employees for any other reason.

76. 81 Sup. Ct. 1784 (1961).

77. Id. at $1790,1798-1801$.

78. Of course, the history of union security under the Railway Labor Act, 44 Stat. 577 (1926), as amended, 45 U.S.C. \$§ 151-88 (1958), differs from that under Taft-Hartley. Under the latter, the amount of union security available to organized labor has been reduced over the years. See text accompanying notes $28-29$ supra. Under the former it has been expanded; for even the union shop was banned from 1926 until the amendment of the Act in 1951, which specifically permitted the union shop on the railroads. See Railway Labor Act § 2 Eleventh, 64 Stat. 1238 (1951), 45 U.S.C. \$ 152 Eleventh (1958). Arguably, this difference in the history of the two statutes as they relate to union security could in the future be reflected by a judicial unwillingness to apply a doctrine valid under one of them to a case governed by the other.

79. "Checkoff" is a process by which management deducts union security payments from workers' wages, tendering them directly to the union. It, too, is limited by many right-to-work statutes. See, e.g., S.C. CoDE ANN. § 40-46.4 (Supp. 1960).

80. Labor-Management Reporting and Disclosure Act $\S \S 201$ (b) \& 205, 73 Stat. 524,528 (1959), 29 U.S.C. $\$ \$ 431$ (b) \& 435 (Supp. I 1959), make certain union financial transactions a matter of public record. But the employer examination necessitated by checkoff of such a union security payment as that discussed in text at note 78 supra would probably have to be more detailed than that afforded by the Act.

81. Moreover, the NLRB probably has no jurisdiction to award such a remedy. Conceivably, the remedial powers accorded the Board by Labor-Management Relations Act $\S$ 
Absent some means for the proper allocation of agency shop support money, therefore, the Board should find the agency shop-closed union situation outside the protection of section 8 (a) (3).

\section{Implications Under State Lawe}

Another interesting question invited by the Board's holding in General Motors Corp. is its potential effect upon the law of right-to-work states. Technically, the second decision does not affect state law at all; by declaring the agency shop legitimate under section 8 (a) (3), the Board has left the states free to prohibit or allow it. ${ }^{2}$ Here, again, Member Leedom's "coercion" argument becomes relevant because the allowance of the agency shop in a right-towork state may well undercut the policy implicit in the state law. By enacting a right-to-work law the legislature may well have intended to grant each employee absolute freedom of association; and the required payment of dues to an objectionable organization would by itself, and by virtue of the fact that it coerces dues paying nonmembers to join, deny, or at least restrict, such freedom; legislation premised on such an intent would, indeed, be subverted by judicial approval of the agency shop. But the policy behind a law prohibiting the conditioning of employment upon union membership may reflect a legislative compromise between the protection of individual freedom of association and the protection of the interests of the union in obtaining financial support from those whom it represents. Such a statute, therefore, might have been intended to prohibit the requirement of actual membership-the most onerous restriction on associational freedom-but to permit the requirement of financial support-a more limited restriction on associational freedom which, in the contemplation of the legislature, may have been outweighed by the union's interest in such support. Judicial approval of the agency shop would, of course, be perfectly consistent with a right-to-work law which reflected such a compromise. The Indiana Appellate Court in $\mathrm{Hagberg}^{83}$ was the first state tribunal to pass on the legality of the agency shop under a statute prohibiting the conditioning of employment upon union "membership." The court apparently inferred a policy of legislative compromise from the fact that, although the Indiana statute was enacted subsequent to other state statutes containing explicit prohibition of the agency shop, it contained no reference to the agency shop. $^{84}$

Another approach to this problem appears in a recent Kansas decision, Higgins v. Cardinal Mfg. Co. ${ }^{85}$ There, the Kansas Supreme Court ruled on the legal-

10 (c), 61 Stat. 147 (1947), 29 U.S.C. $\$ 160$ (c) (1958), might be stretched to allow this type of relief; normally, however, affirmative relief is limited to reinstatement and awards of back pay.

82. See note 57 supra and accompanying text.

83. Meade Elec. Co. v. Hagberg, 129 Ind. App. 631, 159 N.E.2d 408 (1959).

84. Id. at $641-43,159$ N.E.2d at $413-14$.

85. 360 P.2d 456 (1961), cert. deried, 30 U.S.L. WEEK 3107 (October 10, 1961) (No. 208). 
ity of an agency shop provision under a right-to-work constitutional amendment similar in wording to the Indiana statute. The union contended, as in Hagberg, that the state's right-to-work provision, being one of the last adopted, should be read, in light of the existence of earlier statutes in other states specifically outlawing the agency shop, not to ban the device. ${ }^{86}$ This argument was buttressed by the earlier failure of the Kansas legislature to enact a proposed bill containing the more restrictive language. In further support of their position, the union counsel pointed to the Hagberg case. ${ }^{87}$ However, the court found Hagberg distinguishable because: (1) it involved a legislative act requiring stricter construction than the constitutional provision embodying the Kansas "right-to-work" policy; (2) the Indiana statute contained a penal provision, which also demanded strict construction. ${ }^{88}$ In divining the intent of the Kansas legislature which had drafted the amendment, the court assumed that that body had attempted to ban all union security permitted by the federal statute. It observed that, even under the union shop, a union could, under federal law, require only the tender of dues and fees as a condition of employment; hence, the court reasoned that the agency shop could, in effect, be equated with the union shop in the context of union security. ${ }^{89}$ Section $14(\mathrm{~b})$, reasoned the court, allowed the states to prohibit all such arrangements. Thus, in the court's view, the detailed provisions in earlier statutes were surplusage, ${ }^{80}$ and the "rather well-hidden meaning" of the Kansas provision included a ban of the agency shop. ${ }^{91}$ The alternative reading, felt the court, would require a declaration that the whole amendment served no useful purpose whatsoever. ${ }^{92}$

\section{Conclusion}

The decision of the Kansas court squarely presents the conflict between the policies implicit in a right-to-work law and those underlying union security. If, as Higgins suggests, a state must ban the agency shop in order to effectuate its ban of the union shop-and the second General Motors Corp. case leaves the states the discretion to do this-the union loses all power to exact financial support from those for whom, under federal law, it must bargain. In such a case, one may, perhaps, conclude that section 14(b) does not reflect a wise delegation of power to the states. For the National Labor Relations Act and its Taft-Hartley amendments reflect a conscious choice between total government regulation of wages, hours, and working conditions, and a scheme in which these details are worked out through the interaction of private groups in the
86. 360 P.2d at 463 .
87. Ibid.
88. 360 P.2d at $463-64$.
89. 360 P.2d at $464-65$.
90. 360 P.2d at $465-66$.
91. 360 P.2d at 465 .
92. 360 P.2d at 466 . 
collective bargaining process. ${ }^{93} \mathrm{~A}$ logical correlative of elevating the union to such a position is granting it the right to require whatever financial support may be necessary for the proper performance of its collective bargaining functions. Quite possibly, section 14(b), in allowing states to deny that right, is not consonant with the remainder of the federal statutory scheme. Neither $S(a)(3)$ nor 14 (b) is more than permissive..$^{94}$ But if allowing union security is more in keeping with the basic policies of the statute than allowing states to prohibit it, Congress should seek some means of forbidding state prohibition of the agency shop. If Higgins is correct in reading section 8(a)(3) as permitting, in effect, no more than an agency shop, a federal statute denying the states the right to ban the agency shop would effectively invalidate ${ }^{95}$ all existing right-to-work laws. Such a result might better comport with national labor policy than does section 14 (b) as presently written. ${ }^{96}$

93. See Cox, Some Aspects of the Labor Management Relations Act, 1947, 61 HARV. L. Rev. 1, 1-2 (1947).

94. See notes $21 \& 39$ sipra.

95. Right-to-work laws would no longer govern operations in interstate commerce; their effect would be limited to the ever-narrowing area of purely intrastate matters.

96. For an interesting non-legal epilogue to the problems raised by the decisions of the NLRB in Genteral Motors Corp., see three columns written by Arthur Krock appearing in N.Y. Times, Oct. 5, 1961, p. 36, col. 4; id., October 13, 1961, p. 34, col. 4; id., October 20, 1961, p. 32, col. 4. 